\title{
PERPUSTAKAAN GEDONG KERTYA DI KOTA SINGARAJA (PENGELOLAAN DAN KEBIJAKAN PEMERINTAH DAERAH DALAM PENGEMBANGANNYA SEBAGAI LEMBAGA PRESERVASI KEBUDAYAAN BALI)
}

\author{
Luh Putu Sri Ariyani, Made Mas Hariprawani, Ni Wayan Sri Budi \\ UPT Perpustakaan, Universitas Pendidikan Ganesha \\ Singaraja Indonesia
}

Email: putu.sri77@gmail.com

\begin{abstract}
Abstrak
Penelitian ini bertujuan untuk: (1) Memahami sistem pengelolaan perpustakaan Gedong Kertya dalam wujud praktik-praktik sosial; (2) Memahami kebijakan Pemerintah Kabupaten Buleleng dalam rangka menumbuhkembangkan perpustakaan Gedong Kertya sebagai asset daerah yang menyimpan kekayaan intelektual masyarakat Bali. Metode yang digunakan dalam penelitian ini adalah penelitian kualitatif dengan memahami fenomena sosial dari perspektif partisipan atau menurut perspektif emik. Hasil penelitian menunjukkan bahwa pengelolaan perpustakaan Gedong Kertya sangat khas karena layanan yang diberikan di tempat itu tidak ditemukan pada perpustakaan lainnya. Kebijakan yang mengatur tentang sumber daya manusia maupun sumber daya finansial di Gedong Kertya hingga saat ini belum ada sehingga kebutuhan yang diperlukan belum bisa tercapai dengan optimal. Anggaran yang sangat minim telah menyebabkan Gedong Kertya terpaksa menghentikan kegiatan yang dianggap penting bagi kelangsungan kebudayaan Bali.
\end{abstract}

Kata kunci: pengelolaan perpustakaan, Gedong Kertya, lontar, kebijakan.

\begin{abstract}
This study aims to: (1) understand the library management in Gedong Kertya in the form of social practice; (2) understand the government policy of Buleleng regency in developing Gedong kertya as the asset that has intellectual property of Balinese. This study uses qualitative research methods to understand social fenomenon from the perspective of participants. The results of this research showed that the management of Gedong Kertya is very unique and cannot find at the other libraries. The policy about human resources and financial resources in Gedong Kertya never exist so that everything they need in managing their library cannot realize and this caused the services given to user is not optimal. Limited financial resource pushed Gedong Kertya to stop any activities that remain important for sustainability of Balinese culture.
\end{abstract}

Keywords: Library management, Gedong Kertya, lontar, policy. 


\section{PENDAHULUAN}

Masyarakat Bali sangat terkenal karena keunikan kebudayaannya (Covarrubias, 1972: p. 17). Hal ini tercermin dari berbagai bentuk artefak yang dihasilkannya, salah satunya berwujud manuskrip kuno yang dikenal dengan nama lontar. Lontar merupakan tulisan yang dibuat di atas lembaran ron (daun) ental (siwalan). Lontar sangat penting karena di dalamnya terdapat kekayaan intelektual masyarakat Bali, misalnya tentang agama dan filsafat Hindu, arsitektur, cerita rakyat, pengetahuan tradisional tentang obatobatan (usada), bahkan ilmu hitam (pengliakan) dan cetik (racun).

Kandungan pengetahuan dalam lontar mengundang perhatian berbagai pihak termasuk orang Belanda. Perhatian orang Belanda, sebagaimana dikemukakan Said (2011 : p. 3), pertama kali dilakukan oleh para orientalis pada tahun 1920-an - yakni pada masa penjajahan Belanda. Mereka tidak saja mengumpulkan berbagai jenis lontar yang tersebar pada komunitas lokal di Bali, tetapi juga melestarikan lontar tersebut melalui pendirian perpustakaan, yakni Perpustakaan Gedong Kertya yang terletak di kota Singaraja, Buleleng, Bali.

Perpustakaan ini tidak saja mengoleksi berbagai jenis lontar, tetapi juga karya tulis klasik tentang Bali, termasuk di dalamnya laporan para pejabat Belanda yang berkuasa di Bali pada abad ke XIX. Perpustakaan Gedong Kertya memuat pula majalah terbitan tahun 1920-an, yakni Majalah Surya Kanta dan Majalah Bali Adnyana. Meskipun demikian koleksi utamanya tetap adalah lontar sehingga tidak mengherankan jika Perpustakaan
Gedong Kertya lazim disebut perpustakaan lontar.

Selain keunikan koleksinya, Gedong Kertya memiliki kekekhasan dalam preservasi pengetahuan yang dilakukan di Gedong Kertya berkaitan dengan sistem pengelolaan preservasi pengetahuan tentang preservasi fisik lontar agar tidak rusak, termasuk pula kandungan isinya - sehingga nilai-nilai kebudayaan Bali dapat tetap dinikmati oleh banyak orang. Dengan demikian dilihat dari sistem pengelolaan preservasi pengetahuan yang berhubungan dengan materi fisik dan intelektual yang telah dijalankan terhadap koleksinya, maka Gedong Kertya memerlukan strategi, bagaimana lembaga ini mempertahankan dan mengembangkan suatu sistem pengelolaan preservasi pengetahuan yang mampu mengakomodasikan kekhasan yang dimilikinya, dengan ketentuan yang tidak mengabaikan pengelolaan yang bersifat universal, yang berlaku di arena perpustakaan.

Perpustakaan Gedong Kertya sebagai suatu lembaga perpustakaan, tidak hanya membutuhkan kapital artefaktual, yakni lontar kuno sebagai koleksinya, tetapi memerlukan pula kapital lainnya, seperti kapital sosial, kapital intelektual termasuk di dalamnya sumber daya manusia (SDM) atau modal insani, kapital ekonomi (finansial), kapital natural, dan kapital kultural (Bourdieu:2010; Hasbullah: 2006). Pengamatan kancah menunjukkan kepemilikan kapital insani di Gedong Kertya sangat terbatas. Jumlah karyawan memang mencukupi, namun dilihat dari segi kualifikasi atau latar belakang pendidikan, patut dipertanyakan. Misalnya, menyangkut 
tidak adanya karyawan yang memiliki latar belakang ilmu-ilmu humaniora seperti ilmu perpustakaan, pendidikan bahasa dan sastra Jawa Kuno dan Bahasa dan Sastra Bali - sebab banyak Iontar berbahasa Jawa Kuno dan Bali Kuno atau Bali Tengahan, begitu pula dengan tidak adanya pegawai dengan latar belakang seperti ilmu sejarah, arkeologi - epigrafi - koleksi lontar terkait dengan sejarah dan konteks budaya yang melingkupinya. Selain capital insane yang dianggap kurang, komponen kapital lain dalam sistem pengelolaan secara umum Perpustakaan Gedong Kertya juga bersifat serba terbatas. Akibatnya, timbul kesan, baik Gedong Kertya sebagai lembaga maupun karyawannya, merupakan kumpulan orang termarjinalisasi. Walaupun berada dalam kondisi termarginalisasi, namun kenyataannnya Perpustakaan Gedong Kertya tetap dapat mempertahankan eksistensinya. Kondisi ini menyebabkan Perpustakaan Gedong Kertya menarik untuk dikaji, terutama berkaitan pengelolaan serta kebijakan yang mengatur keberlangsungan tempat ini. Makalah ini akan membahas tentang pengelolaan Perpustakaan Gedong Kertya dan kebijakan yang ditetapkan di sana sebagai wujud pemberian layanan perpustakaan secara optimal.

\section{METODE PENELITIAN}

Metode yang digunakan dalam penelitian ini adalah penelitian kualitatif dengan memahami fenomena sosial dari perspektif partisipan atau menurut perspektif emik. Mereka adalah pelaku sehingga mereka yang paling paham atas apa yang mereka lakukan. Pemahaman orang luar hanya bersifat melengkapi. Untuk itu pengumpulan data penelitian adalah dengan wawancara mendalam, studi dokumentasi dan observasi partisipatif. Setelah melakukan wawancara, data yang ada dianalisis dengan melakukan serangkaian kegiatan yaitu: reduksi data, penyajian data, penafsiran dan penarikan kesimpulan.

\section{HASIL DAN PEMBAHASAN}

Kegiatan menulis lontar merupakan aktivitas yang sudah diwarisi secara turun temurun oleh orang Bali. Lontar berisikan berbagai jenis pengetahuan seperti kesusasteraan, agama, kebudayaan, pengobatan, catatan harian dan lain sebagaianya. Lontar sangat menarik perhatian para ilmuwan di era pemerintah kolonial Belanda. Mereka menyadari bahwa di Bali terdapat begitu banyak kebudayaan yang bersifat unik, khususnya yang berbasis agama Hindu.

Cendekiawan Belanda yang bernama F.A. Liefrink dan Dr. Herman Neubronner Van der Tuuk mendedikasikan hidupnya untuk menulis buku tentang Bali dan mengantarkan Bali menjadi semakin terkenal di kancah Internasional. Untuk mengenang jasa mereka berdua, pada tanggal 2 Juni 1928, L.J.J. Caron seorang residen pemerintah Belanda untuk Bali dan Lombok bersama-sama dengan para raja dan pemuka agama dari seluruh Bali membentuk yayasan (stichting) yang dinamakan Kertya Liefrink-Van der Tuuk. Nama Kertya merupakan nama yang diusulkan oleh I Gusti Putu Djelantik, Raja Buleleng yang berasal dari bahasa Sansekerta yang memiliki arti jerih payah dan pengetahuan. Selain untuk menghormati jasa kedua orang 
tersebut, yayasan ini juga bertujuan melacak naskah lontar yang ditulis dalam bahasa Jawa Kuno dan Pertengahan, bahasa Bali dan Sasak. Selain itu, kegiatan yang dilakukan di yayasan ini adalah berbagai aktivitas intelektual seperti menerbitkan buku dan majalah.

Pada tanggal 14 September 1928, yayasan ini dibuka untuk umum oleh Gubernur Jenderal Hindia Belanda A.C.D. de Graff. Untuk mengingatkan tanggal bersejarah tersebut, pada pintu masuk yayasan tersebut dipahatlah sebuah candra sengkala yang menandakan tanggal pembukaan yayasan tersebut dalam tahun Saka, yaitu gambar manusia menaiki gajah dengan busur panah di tangannya dan orang yang terkena panah itupun mati. Makna dari Chandra Sengkala tersebut adalah sebagai berikut: manusia nilainya 1; gajah (asta-diggaja) nilainya 8; panah (panca-bana) nilainya 5 dan orang mati (sunya) nilainya 0 . Jadi gambar Chandra Sengkala tersebut menunjukkan tahun Saka 1850 atau 1928 Masehi.

Dalam perkembangan selanjutnya, para sarjana Belanda dibantu oleh cerdik pandai yang berasal dari Bali mengeluarkan terbitan berupa Mededeelingen atau majalah. Majalah ini terus berkembang dan hingga tahun 1930, yayasan ini sudah menerbitkan lima nomor. Yayasan Kertya LiefrinkVan der Tuuk juga menerbitkan buku atau teks sejarah. Terbitan pertama adalah Kidung Pamancangah yang diterbitkan dalam huruf Latin berikut ulasan dari Dr. C.C. Berg. Tokoh ini juga sangat berjasa dalam hal menemukan salinan Nagara Krtagama di Lombok pada tahun 1894 - pada saat Belanda menyerang Lombok (Riana, 2009: xiii). Terbitan lainnya berupa buku dua jilid yang ditulis oleh Dr. W.F. Stutterheim berjudul Oudhheden van Bali. Buku ini merupakan buku klasik yang membahas tentang Pejeng dan peninggalanpeninggalan purbakalanya. Desa Pejeng dan desa-desa di sekitarnya memang kaya akan peninggalan purbakala karena dahulunya diperkirakan sebagai pusat kerajaan Dinasti Warmadewa.

Saat ini Gedong Kertya berada di bawah pengelolaan Pemerintah Kabupaten Buleleng. Berkenaan dengan itu berarti pula pengelolaan Gedong Kertya sepenuhnya menjadi tanggung jawab Pemerintah Kabupaten Buleleng. Apapun bentuk modal yang dibutuhkan bagi kelangsungan hidup Gedong Kertya, yakni modal insani, modal finansial, modal sosial dan modal teknologi sepenuhnya menjadi tanggung jawab Pemerintah Kabupaten Buleleng.

Koleksi utama Perpustakaan Gedong Kertya adalah lontar. Dengan demikian tidak mengherankan jika Gedong Kertya disebut pula perpustakaan lontar. Jumlah koleksi lontar saat ini adalah lontar asli 1.757 cakep, salinan lontar 7.211 buah (4000an naskah disalin ke dalam lontar, sisanya adalah salinan isi lontar di atas kertas) dan buku 8.490 judul (data statistik perpustakaan Gedong Kertya tahun 2014).

Koleksi lontar yang ada di Gedong Kertya diklasifikasi berdasarkan tulisan I Nyoman Kadjeng yang berjudul "Voorloping Overzicht van de op Bali Aanwezige Literatuurschat". Adapun penggolongan naskah-naskah tersebut adalah sebagai berikut.

(1) Weda. Merupakan Kitab Suci Agama Hindu yang dapat dikelompokkan ke

Jurnal IImu Sosial dan Humaniora |560 
dalam Weda yang berbahasa Sansekerta, Jawa Kuno, dan Bali. Lontar ini terdiri dari Weda Indik Maligia, Weda Pangentas, Weda Panglukatan, dan Weda Sawawedana. Selain itu, lontar yang tergolong sebagai kelompok Weda juga terdiri dari:

a. Mantra yang merupakan doa-doa yang ditujukan kepada Ida Sanghyang Widhi Waça, Tuhan Yang Waha Esa. Judul Iontarnya antara lain: Atmaraksa, Pabersihan, Pangastawa, Pujastawa, Tirta Gamana.

b. Kalpasastra yang berisi tuntunan berbagai ritual Agama Hindu seperti Banten Pangentas, Bebantenan, Caru Suci, Indik Galungan, Manca Balikrama, Pacecaron, Pangabenan, Pawintenan, Plutuk, Sang Kulputih.

(2) Agama. Terdiri dari lontar sebagai berikut:

a. Palakerta yang berisikan berbagai tata aturan kemasyarakatan seperti Agama, Purwadigama, Awig-awig, Kerta ring Sawah, Stri Sanggraha, Pamastuning Cor, Widi Pamincatan, Adigama, Paswara, Kutaragama, dan sebagainya.

b. Sasana yang membahas tentang kesucian moral, terdiri dari Dasa Sila, Dewa Sesana, Kerta Bujangga, Mantra Sesana, Putra Sesana, Raja Sesana, Resi Sesana, Sarasamuscaya, Sila Krama, Sila Sesana, Sang Prabu dan lain-lain.

c. Niti yang mengajarkan hukum dan perundang-undangan pada zaman kerajaan di Bali; lontar yang masuk pada klas ini antara lain Niti Praja, Niti Sastra dan Raja Niti.

(3) Wariga. Merupakan kelompok Iontar yang berisi pengetahuan yang terkait dengan astronomi serta astrologi, ilmu bahasa, bangunan, mitologi dan pengobatan tradisional Bali. Kelompok lontar ini terdiri dari:

a. Wewaran, tentang hari baik dan hari buruk berdasarkan kalender Hindu.

b. Tutur Upadesa, berisikan petuahpetuah dan filosofi Hindu.

c. Kanda, terdiri dari ilmu-ilmu praktis seperti ilmu bangunan, ilmu pengeliakan (black \& white magic).

d. Usadha, koleksi yang berisi tentang pengobatan tradisional.

(4) Ithihasa. Kelompok lontar yang berisikan cerita-cerita kepahlawanan Hindu yang ditulis dalam bahasa Sansekerta, Jawa Kuno, maupun Bahasa Bali. Ithihasa terdiri dari beberapa kelompok yaitu:

a. Parwa, tentang epik Mahabarata yang terdiri dari 18 parwa.

b. Kekawin, merupakan prosa dalam bentuk wirama yang diikat dengan guru lagu. Contohnya: kekawin Sutasoma, Barata Yudha, dan lain-lain.

c. Kidung, adalah tembang yang digubah dalam bentuk bahasa Kawi/Jawa Kuno, contohnya Tantri.

d. Geguritan adalah tembang macapat.

(5) Babad. Merupakan karya sastra yang digolongkan dalam lontar yang menceritakan asal-usul kekeluargaan berbagai klan di Bali dan cerita-cerita yang mengandung unsur sejarah. Kelompok ini terdiri dari: 
a. Babad, tentang silsilah keturunan keluarga-keluarga di Bali seperti Babad Pande, Babad Arya Wang Bang Pinatih, dan lain-lain.

b. Hikayat/Sejarah, contohnya Pararaton.

c. Runtuhnya Kerajaan, contohnya uug Badung, uug Buleleng, dan lain sebagainya.

(6) Tantri. Kelompok lontar yang berisikan cerita pewayangan, folklore, dan catatan muhibah raja-raja di Bali, terdiri dari:

a. Tantri Hindu, yaitu cerita Tantri yang bersumber dari cerita-cerita Hindu di India.

b. Tantri Bali, yaitu Satua Pegantihan (folklore) asli Bali.

c. Surat Pengeling-eling, yaitu suratsurat dari para Raja yang ditujukan kepada rakyatnya.

(7) Lelampahan. Merupakan kelompok lontar yang berisikan skenario atau lakon pertunjukan kesenian-kesenian di Bali seperti kesenian gambuh, arja, wayang, drama gong dan pertunjukan kesenian lainnya.

\section{Berdasarkan penggolongan naskah-naskah yang tersimpan di} Gedong Kertya maka jelas terlihat bahwa isinya beragam. Walaupun isinya sangat beragam namun sangat kental bemuatan Agama Hindu. Dengan demikian maka tidak berlebihan jika dikatakan bahwa Gedong Kertya tidak saja memuat kekayaan budaya Bali, tetapi juga nilai-nilai moralitas yang sangat berguna bagi penumbuhkembangan masyarakat Bali yang berbasiskan Agama Hindu.

Koleksi yang terdapat di sana sebagain besar merupakan koleksi yang berasal pada masa Pemerintahan
Kolonial Belanda. Pada masa itu, upaya pengadaan koleksi dapat dilakukan dengan lebih mudah karena pemerintah penjajahan dapat menyita begitu saja koleksi lontar yang dimiliki oleh masyarakat baik yang dimiliki oleh perseorangan maupun sebuah klan. Tentu saja tidak semua koleksi lontar diperoleh dengan cara ini, banyak pula lontar yang diperoleh secara sukarela dari masyarakat yang menyerahkan lontar koleksinya secara sukarela atau dengan imbalan uang.

Pada masa sekarang ini, pengadaan koleksi lontar di Gedong Kertya saat ini dilakukan dengan cara, 1) membeli dari masyarakat perorangan atau klen, 2) meminjam dari masyarakat untuk disalin, 3) menerima penyerahan lontar dari perseorangan atau klan, dan 3) membuat lontar baru dari berbagai sumber yang semula ditulis dalam tulisan latin pada media kertas.

Mengingat Gedong Kertya merupakan perpustakaan khusus, maka layanan yang ada di sana juga berbeda dengan perpustakaan pada umumnya. Layanan yang dimiliki perpustakaan Gedong Kertya antara lain: (a) Layanan transkripsi dan penerjemahan lontar; (b) konsultasi pemberian nama anak; (c) konsultasi Dewasa Ayu; (d) konsultasi pengobatan tradisional; (e) pelayanan pembacaan lontar atau prasasti; (f) layanan pembelian lontar; (g) layanan membuat Prasi; (h) saksi ahli di pengadilan; (i) penulisan awig-awig desa pakraman mamakai huruf dan bahasa Bali.

Koleksi Gedong Kertya terdiri dari lontar beserta naskah dan buku-buku kuno yang memiliki kandungan pengetahuan yang bernilai sangat tinggi bagi masyarakat Bali. Oleh sebab itu 
tindakan pelestarian atau preservasi, konservasi dan restorasi terhadap koleksi tersebut menjadi kegiatan yang sangat vital bagi perpustakaan ini untuk menjaga kelangsungan koleksi secara fisik dan isinya. Kegiatan preservasi adalah tindakan yang diambil untuk mengantisipasi dan mencegah kerusakan koleksi. Kegiatan ini dapat dilakukan dengan beberapa cara yaitu tindakan konservasi pencegahan (preventive conservation), yang merupakan praktek pemeliharaan koleksi dengan cara menjaga lingkungan sehingga kerusakan atau kehancuran koleksi dapat diminimalisir (Kosilov, 2010). Selain tindakan konservasi pencegahan, tindakan yang tak kalah pentingnya dalam preservasi adalah interventive conservation, tindakan mengurangi resiko kerusakan koleksi seperti: preservasi gedung, penataan lingkungan, preservasi perabot dan peralatan, preservasi melalui kropak seng dan kropak kayu, preservasi terhadap lontar, dan perbaikan lontar yang rusak.

Sebagaimana diamanatkan dalam UU Cagar budaya No. 11 tahun 2010 pasal 1, bahwa setiap tempat yang menyimpan barang budaya perlu dilestarikan keberadaanya karena memiliki nilai penting bagi sejarah, ilmu pengetahuan, pendidikan, agama dan/atau kebudayaan melalui proses penetapan. Gedong Kertya sebagai perpustakaan lontar menyimpan berbagai naskah yang mengandung nilai sejarah, pendidikan, agama dan lain sebagainya dapat dikategorikan sebagai cagar budaya perlu mendapat perhatian agar berbagai artefak yang dimiliki di dalamnya tetap terjaga dan lestari agar pengetahuan yang terkandung pada lontar bisa menjadi ingatan bukan hanya bagi orang Bali tetapi juga bagi dunia.

Sumber daya manusia merupakan unsur yang paling penting dalam penyelenggaraan sebuah organisasi karena SDM adalah modal atau asset yang sangat berharga. SDM juga sering disebut sebagai modal insani. Berbicara tentang sumber daya manusia tidak bisa dilepaskan dari manajemen SDM yang juga menyangkut perencanaan, penyusunan karyawan, pengembangan karyawan, dan lain-lain.

Berdasarkan wawancara terhadap Kepala Gedong Kertya, begitu pula berdasarkan pengamatan, kondisi ini terlihat misalnya pada fakta Gedong Kertya sebagai perpustakaan sama sekali tidak memiliki tenaga pustakawan. Koleksi Gedong Kertya berkaitan dengan kebudayaan Bali yang termuat dalam lontar yang ditulis dalam huruf Bali dan berbahasa Jawa Kuno atau Bahasa Sansekerta. Lontar tersebut juga kaya akan pengetahuan tentang agama Hindu yang mencakup masalah tattwa, susila, dan upakara. Berkenaan dengan itu maka modal insani yang dibutuhkan oleh Gedong Kitya adalah tenaga yang memiliki latar belakang pendidikan antropologi, agama Hindu, bahasa Bali dan Jawa Kuno. Namun, kualifikasi tenaga seperti ini sama sekali tidak ada di Gedong Kertya. Sedangkan tenaga SMA lebih banyak mengurusi masalah administrasi sehingga sama sekali tidak ada kaitannya dengan masalah pengkajian terhadap lontar.

Pihak Gedong Kertya dalam setiap kesempatan selalu mengajukan kepada atasannya bahwasannya mereka memerlukan karyawan yang memiliki kemampuan dalam mengelola lontar, 
namun hal tersebut tidak pernah mendapat sambutan dari pihak yang lebih berwenang sehingga kegiatan di Gedong Kertya tidak ada peningkatan berarti. Pengangkatan pegawai di tempat ini pun tak pernah melalui proses perencanaan. Kapan saja Gedong Kertya bisa kedatangan pegawai baru yang tak pernah direncanakan keberadaannya. Kondisi modal insani seperti ini menimbulkan kesan bahwa posisi Perpustakaan Gedong Kertya hanya dianggap sebagai lembaga pelengkap dari struktur birokrasi secara keseluruhan. Ketiadaan kebijakan terkait sumber daya manusia menjadi bukti bahwasannya pekerjaan yang tercakup dalam Perpustakaan Gedong Kertya tidak dianggap sebagai pekerjaan berbasis profesionalisme, tetapi hanya sebagai pekerjaan administratif sehingga siapa pun bisa melaksanakannya asalkan ada kemauan. Jadi, prinsip dasar keprofesionalan dikesampingkan karena yang dipentingkan adalah kemauan asalkan mau, kemampuan tidaklah penting.

Selain sumber daya manusia yang memadai, komponen penting dalam pengelolaan Gedong Kertya adalah anggaran atau modal financial yang sangat diperlukan bagi kelangsungan operasional perpustakaan ini. Kegiatan rutin yang dilaksanakan di Gedong Kertya meliputi pelestarian koleksi, penyalinan lontar, alih aksara, alih bahasa dan sebagainya. Semua kegiatan tersebut memerlukan dukungan dana yang cukup sehingga koleksi yang dimiliki Gedong Kertya tetap terjaga kondisi maupun kuantitasnya demi kelancaran pelayanan koleksi terhadap pengunjung.
Modal finansial yang dibutuhkan bagi pendanaan Gedong Kertya berasal dari APBD (Anggaran Pendapatan dan Belanja Daerah) Pemkab Buleleng. Secara struktural Gedong Kertya berada di bawah Dinas Kebudayaan dan Pariwisata. Berkenaan dengan itu maka modal finansial bagi Gedong Kertya menyatu dengan anggaran Dinas Kebudayaan dan Pariwisata. Dana yang dialokasikan untuk Gedong Kertya amat kecil, karena ada kecenderungan baik Pemkab Buleleng, begitu pula Dinas Kebudayaan dan Pariwisata, bahkan termasuk DPRD Kabupaten Buleleng, kurang memperhatikan kebutuhan modal finansial Gedong Kertya.

Kecilnya anggaran yang diterima oleh Gedong Kertya memaksa Gedong Kertya untuk menghapus beberapa program rutin yang biasanya dilaksanakan dalam setiap tahunnya. Salah satu contoh program rutin yang ditiadakan di Gedong Kertya adalah lomba nyastra yang biasanya dilakukan sekali dalam setahun. Lomba nyastra biasanya diikuti oleh pelajar mulai tingkat SD hingga SMA se-kabupaten Buleleng sebagai upaya untuk menumbuhkan kecintaan anak sekolah terhadap lontar dan bahasa Bali. Pemenang lomba nyastra biasanya dipersiapkan untuk mengikuti lomba nyastra tingkat provinsi yang diadakan pada saat Pesta Kesenian Bali di kota Denpasar.

Kegiatan lain yang dihapuskan karena kecilnya anggaran Gedong Kertya adalah sosialisasi lontar ke desadesa. Biasanya Gedong Kertya melakukan identifikasi terhadap lontar yang ada di masyarakat sebagai upaya untuk menyelamatkan naskah penting yang masih berada di tangan warga 
masyarakat. Pada saat sosialisasi, apabila ditemukan lontar yang belum dimiliki Gedong Kertya maka akan diupayakan untuk meminjam lontar tersebut atau membelinya. Upaya ini sangat berguna bagi perkembangan koleksi yang dimiliki Gedong Kertya sehingga dengan berkembangnya koleksi yang dimiliki akan meningkatkan kualitas layanan di sana.

Ketiadaan kebijakan yang khusus mengatur tentang Gedong Kertya menjadi penyebab kurang optimalnya pengelolaan Gedong Kertya. Kurangnya SDM yang memadai serta sumber daya financial yang disediakan menjadikan tempat ini kian marjinal diantara gedung-gedung di sekitarnya.

\section{PENUTUP}

Berdasarkan hasil penelitian yang disajikan pada bab pembahasan dapat disimpulkan bahwa berbagai kegiatan mulai dari pengelolaan koleksi, layanan hingga kegiatan preservasi yang dilakukan di Perpustakaan Gedong Kertya bersifat unik dan khas. Dari segi pengelolaan koleksi, Perpustakaan Gedong Kertya melakukan berbagai kegiatan yang tidak jauh berbeda dengan perpustakaan pada umumnya. Koleksi yang dimiliki oleh Perpustakaan Gedong Kertya sebagian besar merupakan koleksi yang berasal dari zaman Belanda, namun hingga sekarang perpustakaan ini terus melakukan pengembangan koleksi. Pengadaan koleksi di sana dilakukan dengan beberapa cara seperti: pembelian, sumbangan, penyalinan, serta menerbitkan sendiri. Untuk pengolahan bahan pustaka berupa klasifikasi, katalogisasi hingga penomoran dan penjajaran di dalam rak, perpustakaan Gedong Kertya memiliki sistem tersendiri yaitu diklasifikasi menjadi tujuh bidang yaitu: Weda, Agama, Wariga, Ithihasa, Babad, Tantri dan Lelampahan. Untuk sistem penomoran pun Gedong Kertya menciptakan kode sendiri yang dianggap lebih mudah dalam temu kembali informasi. Sementara penempatan koleksi pada rak, Gedong Kertya menjajarkannya berdasarkan bahasa, keaslian koleksi serta penerbit koleksi itu sendiri.

Untuk layanan, mengingat sebagian besar koleksi Perpustakaan Gedong Kertya adalah manuskrip berupa lontar dan buku-buku kuno yang langka dan tidak ada duanya, layanan sirkulasi berupa peminjaman dan pengembalian bahan pustaka tidak ada di sana. Layanan yang diberikan sebagian besar merupakan layanan referensi berupa layanan bimbingan membaca dan menulis aksara Bali kepada pengunjung. Layanan lainnya adalah layanan yang bersifat praktis dan sangat dekat dengan kehidupan seharihari masyarakat Hindu Bali seperti: layanan transkripsi dan penerjemahan lontar, konsultasi pemberian nama anak, konsultasi dewasa ayu, konsultasi pengobatan tradisional, layanan pembacaan prasati, dan lain-lain.

Untuk tindakan preservasi koleksi berupa konservasi pencegahan dilakukan dengan menjaga agar desain yang diwariskan pada zaman Belanda tetap pada aslinya. Lingkungan sekitar juga dijaga guna mempertahankan keutuhan koleksi yang ada. Kondisi cuaca yang panas harus didukung dengan lingkungan yang sejuk agar koleksi khususnya lontar tidak melengkung karena panas. Berbagai 
perabot seperti rak dan kropak juga sangat diperhatikan guna menjaga kekuatan koleksi. Masih banyak perabotan yang berasal dari zaman Belanda dipergunakan dalam penyimpanan koleksi yang ada di sana, disamping ada juga aneka perabot yang baru. Perabot yang dimaksud, selain memberikan nilai estetika, juga merupakan upaya pencegahan dari kerusakan koleksi. Upaya pencegahan dengan melindungi fisik lontar dilakukan dengan cara modern dan tradisional yaitu dengan menggunakan kapur arus dan silica gel. Cara tradisional yaitu dengan mengaplikasikan minyak sereh dan kemiri bakar pada lontar sehingga lontar mudah dibaca dan tetap lentur. Sementara untuk perbaikan koleksi yang rusak khususnya lontar dilakukan dengan cara yang sangat sederhana, yaitu dengan diberikan selotip dan yang rusak parah dibuatkan salinannya.

Ketiadaan kebijakan yang khusus mengatur Gedong Kertya menjadi salah satu penyebab kurang diperhatikannya Gedong Kertya. Keberadaan perpustakaan ini hanya dianggap sebagai pelengkap diantara gedunggedung lain yang ada di Buleleng. Untuk itu diperlukan kesadaran berbagai pihak termasuk tokoh masyarakat untuk mendorong pemerintah beserta jajaran terkait untuk memperhatikan tempat ini dengan lebih baik sehingga Gedong Kertya tidak menjadi kebanggaan masyarakat Buleleng tetapi juga masyarakat dunia. Gedong Kertya apabila diperhatikan dengan baik, tidak hanya dapat menadi daerah tujuan wisata, tetapi juga dapat menjadi pusat preservasi kebudayaan Bali yang melahirkan generasi yang akan melanjutkan tradisi nyastra di Bali. di
Gedong Kertya juga diharapkan akan lahir berbagai pengetahuan baru yang akan memperkaya khasanah ilmu pengetahuan masyarakat Bali terkait pengetahuan tradisional.

Setiap kendala yang muncul akibat tidak adanya kebijakan yang mengatur Gedong Kertya penanggulangan agar Perpustakaan Gedong Kertya tetap eksis dan bisa berperan secara optimal. Berkenaan dengan itu maka ada beberapa saran tindak yang bisa dikemukakan untuk pengembangan Perpustakaan Gedong Kertya di masa depan.

\section{(a) Penyadaran Kultural}

Langkah paling awal yang bisa dilakukan adalah memberikan penyadaran kultural kepada para aktor penentu kebijakan di lingkungan Pemkab Buleleng dan DPRD Buleleng bahwa Gedong Kertya yang memuat berbagai warisan budaya Bali memiliki kedudukan sangat penting bagi masyarakat Bali. Prinsip dasar penyadaran kultural adalah merubah cara berpikir mereka, yakni melihat kemajuan suatu masyarakat tidak hanya diukur berdasarkan pemenuhan kebutuhan ekonomi yang ditandai oleh pembangunan berbagai prasarana dan sarana ekonomi, tetapi harus pula dilihat dari segi pemenuhan kebutuhan rohaniah atau spiritual yang di dalamnya menyangkut pemenuhan kebutuhan budaya.

\section{(b) Penyediaan Modal Ekonomi Yang Memadai}

Paparan di atas menunjukkan bahwa kelemahan paling mendasar bagi Gedong Kertya adalah miskin akan modal finansial. Gedong Kertya tidak 
memiliki sumber masukan finansial sehingga sepenuhnya bergantung kepada induknya, yakni Pemkab Buleleng. Dengan adanya kenyataan ini maka sudah selayaknya Pemkab Buleleng, begitu pula DPRD Buleleng menyediakan dana khusus untuk menunjang pengoperasian Gedong Kertya lewat APBD. Dana yang diberikan bersifat tepat guna sehingga tidak berdasarkan pada keinginan, tetapi bersandarkan pada kebutuhan nyata. Artinya, dana yang tersedia dimanfaatkan untuk menunjang kegiatan Gedong Kertya. Pemberian bantuan harus disertai dengan pertanggunjawaban yang transparan dan akuntabel. Dengan cara ini diharapkan Gedong Kertya paling tidak mampu memenuhi kebutuhan minimalnya secara berkelanjutan dalam konteks memberikan pelayanan kepada konsumen yang membutuhkan jasa budaya yang termuat pada lontar yang tersimpan di Gedong Kertya.

\section{(c) Peningkatan Keprofesionalan Pegawai}

Pegawai Gedong Kertya perlu ditingkatkan kualitas keprofesionalannya antara lain melalui pendidikan fomal. Idealnya, paling tidak mereka memiliki ijazah D3 Perpustakaan. Kepemilikan ijazah lewat pendidikan formal perlu pula dibarengi dengan penyelenggaraan pendidikan dan atau pelatihan secara berkelanjutan sehingga keprofesionalan mereka terus berkembang. Kondisi ini disertai pula dengan sistem rekrutmen yang memperhatikan kebutuhan nyata, bukan berdasarkan kepentingan para pejabat. Begitu pula kebijakan gaya lama yang memposisikan Gedong Kertya sebagai lembaga pinggiran dan tempat pembuangan pegawai terkena sanksi jabatan perlu diganti dengan citra yang baru, yakni Gedong Kertya adalah lembaga terhormat sebagai tempat bagi seseorang untuk mengaktualisasikan segala potensi yang ada pada dirinya secara optimal. Menjadikan pegawai Gedong Kertya juga sangat penting agar pegawai yang sudah menguasai berbagai keterampilan terkait lontar tidak dengan mudah dimutasi ke tempat lain sehingga pengembangan Gedong Kertya menjadi optimal.

\section{DAFTAR PUSTAKA}

Bourdieu, P. 2010. Arena Produksi Kultural Sebuah Kajian Sosiologi Budaya. [Penerjemah: Yudi Santosa]. Yogyakarta: Kreasi Wacana.

Covarrubias, M. 1972. Island of Bali. Kuala Lumpur: Oxford University Press.

Hasbullah, J. (2006). Social Capital (Menuju Keunggulan Budaya Manusia Indonesia). Jakarta: MRUnited Press.

Kosilov, Andrey. 2010. Knowledge Preservation Method. International Atomic Energy Agency, School of Nuclear Knowledge Management. 23-27 August 2010, Trieste, Italia.

Lubis, Akhyar Yusuf dan Donny Gahral Adian. (2011). Pengantar Filsafat IImu Pengetahuan. Depok: Koekoesan.

Said, Edward W. 2011. Orientalism. Columbia: Vintage.

Jurnal IImu Sosial dan Humaniora |567 